\title{
Effect of grazing on coralline algae in seasonal, tropical, low-shore rock pools: spatio-temporal variation in settlement and persistence
}

\author{
Tak-Cheung Wai, Gray A. Williams* \\ The Swire Institute of Marine Science, Department of Ecology and Biodiversity, The University of Hong Kong, \\ Pokfulam Road, Hong Kong, SAR, China
}

\begin{abstract}
Low-shore rock pools in Hong Kong are dominated by crustose coralline algae (CCA) all year round. Experiments manipulating grazer access to new surfaces and those with established CCA were used to investigate the spatial and temporal effects of grazers on establishment and persistence of CCA. During establishment, CCA were always the first macroalgae to recruit to new surfaces. Predictable algal colonization patterns were observed, although the extent and timing varied spatially (between pools) and temporally (with season and year). Grazing was the primary factor controlling the dominance of the CCA in low-shore rock pools, and seasonal differences in algal composition were only pronounced in the absence of grazers. On new surfaces, where grazers were excluded, the settling CCA were overgrown by competitively superior brown crustose algae (Ralfsia spp.) in summer and by non-crustose macroalgae (Ulva spp., Enteromorpha compressa, Hincksia mitchelliae and/or Colpomenia sinuosa) in winter. On CCA-colonized surfaces, E. compresa was, however, the dominant macroalga in winter in the absence of grazers. As a result of thermal stress in summer, the established CCA were commonly bleached, and new patches of bare surface were subsequently released. Such physical disturbance, hence, re-initiated colonization processes. The rapid re-colonization of CCA on new surfaces by lateral growth and new settlement suggests that CCA are resilient in nature, which results in them being the dominant macroalgae in the lowshore rock pools, all year round, in the presence of grazers.
\end{abstract}

KEY WORDS: Crustose coralline algae $\cdot$ Herbivory $\cdot$ Settlement $\cdot$ Summer heat stress $\cdot$ Persistence Spatial and temporal variation

Resale or republication not permitted without written consent of the publisher

\section{INTRODUCTION}

Disturbance has long been recognized as a primary mechanism driving succession, in which loss of species and biomass from marine habitats is followed by subsequent settlement, recruitment, development and growth of various species (Pickett \& White 1985, Sousa 1985). In intertidal and subtidal habitats, hard substrates are often covered by sessile invertebrates and algae, and are frequently influenced by both abiotic (e.g. physical heat stress) and biotic disturbances (e.g. grazing by echinoids and molluscs; Moore 1972, Lawrence 1975, Hawkins \& Hartnoll 1983). Subsequent consequences of such disturbances can be complex processes in that they are often not predictable and are dependent on different factors such as the extent, frequency and type of disturbance at various spatial and temporal scales (Farrell 1989, Airoldi 2000). Disturbances that are intense enough to create patches of bare surface (e.g. echinoid grazing, wave damage, summer heat stress) are likely to have different subsequent events and consequences than those that are subtle, non-lethal, or only cause partial or selective removal of biomass (e.g. molluscan grazing; Steneck et al. 1991, Dethier \& Steneck 2001). Paths of succession are also affected by the type and characteristics of the new space colonizers, for example, the availability or rate of arrival of new recruits (i.e. larvae and algal pro- 
pagules) and their ability to compete and reproduce in the new environment (Connell \& Slatyer 1977, Sousa 1984).

In intertidal and subtidal habitats, crustose coralline algae (CCA; Corallinales: Rhodophyta) are widely distributed and occupy much of the primary substrate (Johansen 1981). After disturbance, CCA are often the primary colonists of hard substrates in these habitats, and their subsequent survival (i.e. persistence) and dominance (e.g. coralline barren grounds) are associated with intense grazing activity in many shallow marine habitats (Lawrence 1975, Steneck 1986). The processes of establishment of CCA and the successional pathways of algal groups on coralline-dominated substrates under different grazing conditions at various spatial and temporal scales are, however, not well understood in many marine habitats (but see McClanahan 1997, Coleman 2003).

In low-shore rock pools in Hong Kong, CCA are the dominant algal group all year round (HallSpencer 1994). Although grazing is known to be an important factor in algal settlement in these pools (Williams et al. 1995), spatial (e.g. between pool) or temporal (e.g. between season) variation in primary algal settlement and persistence (i.e. the continued existence/survival) of established CCA has not been investigated. The persistence of coralline algae is unlikely to be solely affected by herbivore-induced disturbance; as other factors, such as seasonality, water motion, etc., are also likely to be important (see Johansen 1981, Airoldi \& Virgilio 1998, Connell 2003). In addition, the corallines themselves influence persistence, as they may either facilitate or inhibit the settlement and growth of epiphytes, including erect macroalgae (see Bulleri et al. 2002). The ecological processes and mechanisms responsible for the persistence and succession of coralline algae are, therefore, complex, and may vary in different environments.

Seasonal factors are known to be especially important for coastal systems in Hong Kong, since the hot, wet summer and cold, dry winter have a strong influence on the distribution and diversity of sessile assemblages, especially macroalgae (Hodgkiss 1984, Williams 1993, Kaehler \& Williams 1996, Kennish et al. 1996). Successional processes can operate on different temporal scales (e.g. season) and profoundly influence the organization of assemblages (Benedetti-Cecchi 2000), especially in a strongly seasonal environment such as Hong Kong. The present study investigates the effect of spatial (between pools) and temporal variation (be- tween seasons and years) in grazing, as a form of disturbance, on primary settlement and persistence of CCA, to determine whether there are any predictable patterns of algal succession and development in lowshore pools on seasonal, tropical shores.

\section{MATERIALS AND METHODS}

Site description and study period. A number of lowshore rock pools (Pools 1, 4, 5, 6, 8 and 9; all $\leq 1.5 \mathrm{~m}$ above Chart Datum, C.D.; Table 1) inside the Cape d'Aguilar Marine Reserve, Hong Kong $\left(22^{\circ} 12^{\prime} \mathrm{N}\right.$, $114^{\circ} 15^{\prime} \mathrm{W}$ ) were randomly chosen (see Morton \& Harper 1995 for detailed shore description). As Hong Kong experiences a strongly seasonal climate, dominated by 2 monsoons, experiments were conducted during both summer (June to October, monthly air temperatures 25 to $29^{\circ} \mathrm{C}$, maximum $36^{\circ} \mathrm{C}$, water temperatures $\sim 27^{\circ} \mathrm{C}$ and $>80 \%$ of annual rainfall - designated the hot, wet season) and winter (November to March, monthly air temperatures 15 to $18^{\circ} \mathrm{C}$, water temperatures ca. $17^{\circ} \mathrm{C}$ - designated the cold, dry season; see Kaehler \& Williams 1996 for climatic details).

In all rock pools, CCA were the most abundant algal group and dominated the pool substrates ( $>70 \%$ cover) all year round. The most abundant molluscan grazers were Chlorostoma argyrostoma, Lunella coronata and Nerita albicilla. Small numbers of limpets Cellana toreuma and the sea urchin Anthocidaris crassispina were also present (see Wai 2004, Wai \& Williams 2006 for more details).

Primary algal settlement. Experimental design: Poly-vinyl chlorinated (PVC) plates were used to provide a uniform and repeatable sampling unit (Smith et al. 2001). New bare PVC plates (grey, $25 \times 16 \times 0.4 \mathrm{~cm}$ ) were roughened on a belt sander (Sandpaper Grade 180 for 1 min) and fixed using plastic bolts embedded into a series of holes drilled $\sim 5 \mathrm{~cm}$ below the pool sur-

Table 1. Summary of physical characteristics, tidal level and mean daytime $(07: 00$ to $18: 00 \mathrm{~h})$ isolation period in relation to local predicted tidal patterns (August 2000, Waglan Island, Hong Kong Observatory) of the experimental rock pools at Cape d'Aguilar, Hong Kong (C.D.: Chart Datum)

\begin{tabular}{|ccccccc|}
\hline Pool & $\begin{array}{c}\text { Max. } \\
\text { length } \times \text { width } \\
(\mathrm{cm})\end{array}$ & $\begin{array}{c}\text { Max. } \\
\text { depth } \\
(\mathrm{cm})\end{array}$ & $\begin{array}{c}\text { Volume } \\
(\mathrm{l})\end{array}$ & $\begin{array}{c}\text { Tidal } \\
\text { level } \\
(\mathrm{cm}+\text { C.D. })\end{array}$ & $\begin{array}{c}\text { Mean } \\
\text { daytime } \\
\text { low tide } \\
\text { (h; SD) }\end{array}$ & $\begin{array}{c}\text { Max. } \\
\text { daytime } \\
\text { low tide } \\
(\mathrm{h})\end{array}$ \\
\hline 1 & $622 \times 220$ & 102 & 4230 & 105 & $3.71(2.05)$ & 6 \\
4 & $728 \times 124$ & 149 & 3843 & 150 & $7.19(2.66)$ & 12 \\
5 & $468 \times 172$ & 145 & 3537 & 150 & $7.19(2.66)$ & 12 \\
6 & $688 \times 236$ & 168 & 8266 & 150 & $7.19(2.66)$ & 12 \\
8 & $466 \times 96$ & 65 & 881 & 150 & $7.19(2.66)$ & 12 \\
9 & $1412 \times 746$ & 124 & 39581 & 150 & $7.19(2.66)$ & 12 \\
\hline
\end{tabular}


face using epoxy putty (wet surface epoxy putty, Devcon). The bolts allowed the PVC plates and associated treatments to be easily removed for repeated sampling.

Plates were assigned to 3 treatments: (1) cage, (2) fence and (3) open. The cage treatment was made of galvanized wire mesh (mesh size $1.5 \mathrm{~cm}, 30 \times 20 \times$ $8 \mathrm{~cm})$ and excluded macrograzers $(>1.5 \mathrm{~cm})$ from the plates. The fence treatment was used as a cage control, made in the same way as cages but without the two $20 \times 8 \mathrm{~cm}$ sides, so the open sides allowed grazers access to the plates. The open treatment was a control, with plates only and free access for grazers. Four replicates were randomly established for each treatment, in each of 3 pools (Pools 1, 4 and $6 ; \sum \mathrm{n}=3$ pools $\times 3$ treatments $\times 4$ replicates $=36$ ).

Sampling protocol and data analysis: Experiments were repeated in 2 different years in summer (May to October, 2000 and 2001) and winter (November to March, 2000-01 and 2001-02). The experiments ran for 4 mo in each season, and, every month, plates were removed from the pools during low tide and transferred (inside a cool box with seawater) to the laboratory $(\sim 10$ to 20 min walk) for measurements, and then returned to the same position during the next low tide (i.e. within 12 to $24 \mathrm{~h}$ ). Two scales of photo-quadrats were taken of each plate: (1) macro-quadrats $(15 \times 10 \mathrm{~cm} ; \mathrm{n}=1)$, to record any sea urchin graze marks, and (2) randomly located 'micro'-quadrats $(1.5 \times 1 \mathrm{~cm} ; \mathrm{n}=12)$, to record percentage cover of target groups using a binocular microscope $\left(\right.$ magnification $=6.3 \times_{i}$ Leica Wild MZ8) .

The percentage cover of target groups was estimated by placing a transparent overlay, of 100 equally spaced dots, on the pictures $(10 \times 14 \mathrm{~cm})$ of the 12 'micro'-quadrats. The values counted (i.e. percentage cover of groups, see below) from these quadrats were pooled to give a mean, which was used as a replicate of the corresponding treatment. To minimize potential edge effects, cover within $2 \mathrm{~cm}$ of the edge, or the holes on the plates, was not included. Groups were defined as: (1) CCA (mostly Hydrolithon samoënse, 'Fosliella-state' Hydrolithon sp. and Neogoniolithon misakiense, but also sparse Lithophyllum sp.; see HallSpencer 1994); (2) bleached coralline algae (i.e. dead coralline algae); (3) Ralfsia spp. (brown crusts, mostly $R$. expansa, but also sparse $R$. verrucosa); (4) noncrustose macroalgae (including the green algae Ulva spp. [mostly U. lactuca]; green turfs of Enteromorpha compressa, Chaetomorpha antennina and Cladophora delicatula; the brown algae Hincksia mitchelliae, Colpomenia sinuosa and Endarachne binghamiae; the red alga Gelidium pusillum; green spores); (5) sessile animals (including the tube worms/spirorbid polychaetes Spirorbis foraminosus and Hydroides elegans; rock oysters Saccostrea cucullata and barnacles Balanus amphitrite) and (6) bare surface.
Four-way analysis of variance (ANOVA) was used to test for differences between years (2 levels; orthogonal \& random), seasons (2 levels; orthogonal \& fixed), pools (3 levels; orthogonal \& random) and treatments (3 levels; orthogonal \& fixed) and also any interactions between these factors after 4 mo of colonization/settlement (i.e. data from October 2000 and 2001, summer, and March 2001 and 2002, winter), followed by Student-Newman-Keuls (SNK) multiple comparisons for significant results (Underwood 1997). Cochran's test was performed to test for homogeneity of the data, and data were transformed if necessary (Underwood 1997, see Table 2 legend). As the abundance of Ralfsia spp. and erect macroalgae was $<5 \%$ in winter and summer, respectively, these data were subject to a 3-way ANOVA, to determine differences between years, pools and treatments in summer for Ralfsia spp. and in winter for erect macroalgae, when they were more abundant.

Persistence of crustose coralline algae in space and time. Experimental design: Algal-colonized PVC plates were used to mimic the natural substrate as: (1) this standardizes the substrate and provides a uniform and repeatable sampling unit and (2) the colonization history of the natural substrate in different pools is not known (Smith et al. 2001). To prepare corallinecolonized substrates, new, roughened PVC plates (as described above) were introduced into pools for 5 mo prior to the experiment to achieve $>70 \%$ colonization (similar to the natural rock in the pools). Plates were then transferred to 3 different experimental pools for 1 mo before grazers were excluded (with appropriate controls, as described above) using 3 treatments in winter (December 2001 to April 2002) and in summer (June 2002 to October 2002).

Sampling protocol and data analysis: Sampling and counting methods were the same as above, except that 3-way ANOVA was used to determine whether there were any differences between seasons, pools and treatments and also whether there were any interactions between these factors, after 4 mo of colonization/settlement. Data subjected to analyses were the differences in percentage cover before, and 4 mo after, treatment installation (i.e. values could be positive or negative). As the abundance of erect macroalgae was $<5 \%$ in summer, these data were subjected to a 2 -way ANOVA to determine differences between pools and treatments in winter only.

Grazing pressure. In both experiments, sea urchin grazing pressure was estimated from star-shaped graze marks on the macro-photo-quadrats. The percentage cover of urchin marks was estimated by placing a transparent overlay, consisting of 100 equally spaced dots, on the developed pictures $(10 \times 14 \mathrm{~cm})$. The grazing pressure of the most abundant gastropods 
was monitored using wax discs (see Wai \& Williams 2006 for details). Wax discs (25 mm diameter) were cut from dental wax sheets (0.25 mm thick, Gusswachs), and 8 were evenly stuck onto a PVC plate $(16 \times 8 \times 0.4 \mathrm{~cm})$ by heating in an oven $\left(52^{\circ} \mathrm{C}\right.$ for $\sim 15$ to $\left.20 \mathrm{~min}\right)$. Records of radula and graze marks were obtained from scanning electronic microscope (SEM) images of these specimens and used as a reference to identify marks on the wax discs in the pools.

PVC plates with wax discs were screwed around the top of each pool and left for 3 to $4 \mathrm{~d}$ on 3 randomly chosen dates in summer and winter. The percentage cover of grazer marks of individual species on each disc of each plate was scored as the number of dots of a 100 dot transparent overlay lying over scratches of each species under a binocular microscope $(6.3 \times)$. As smallscale, within-plate differences were not of interest, the mean percentages of the cover of marks on the 8 discs were pooled and treated as a replicate in each pool. To provide background information about which herbivore species grazed in the pools, the overall grazing pressure in each pool, at each sampling period, was standardized as percentage cover per $3 \mathrm{~d}$ (more detailed results are reported in Wai \& Williams 2006). To estimate grazing pressure in the primary settlement experiment, 12 plates were deployed in Pools 1,4 and $6\left(\sum \mathrm{n}=\right.$ 2 seasons $\times 3$ pools $\times 3$ dates $\times 12$ plates $=216$ ), whereas only 8 plates were used in the second experiment to investigate coralline persistence $\left(\sum \mathrm{n}=2\right.$ seasons $\times 3$ pools $\times 3$ dates $\times 8$ plates $=144$ ), as grazing pressure was less variable in Pools 5, 8 and 9 (Wai 2004).

\section{RESULTS}

\section{Primary algal settlement}

In general, algal settlement patterns were strongly affected by grazing in all pools, but the rate of settlement and assemblage development varied spatially and temporally. Bare space diminished in all treatments as algae colonized and grew, and this reduction was usually faster in winter than in summer (Fig. 1), mainly as a
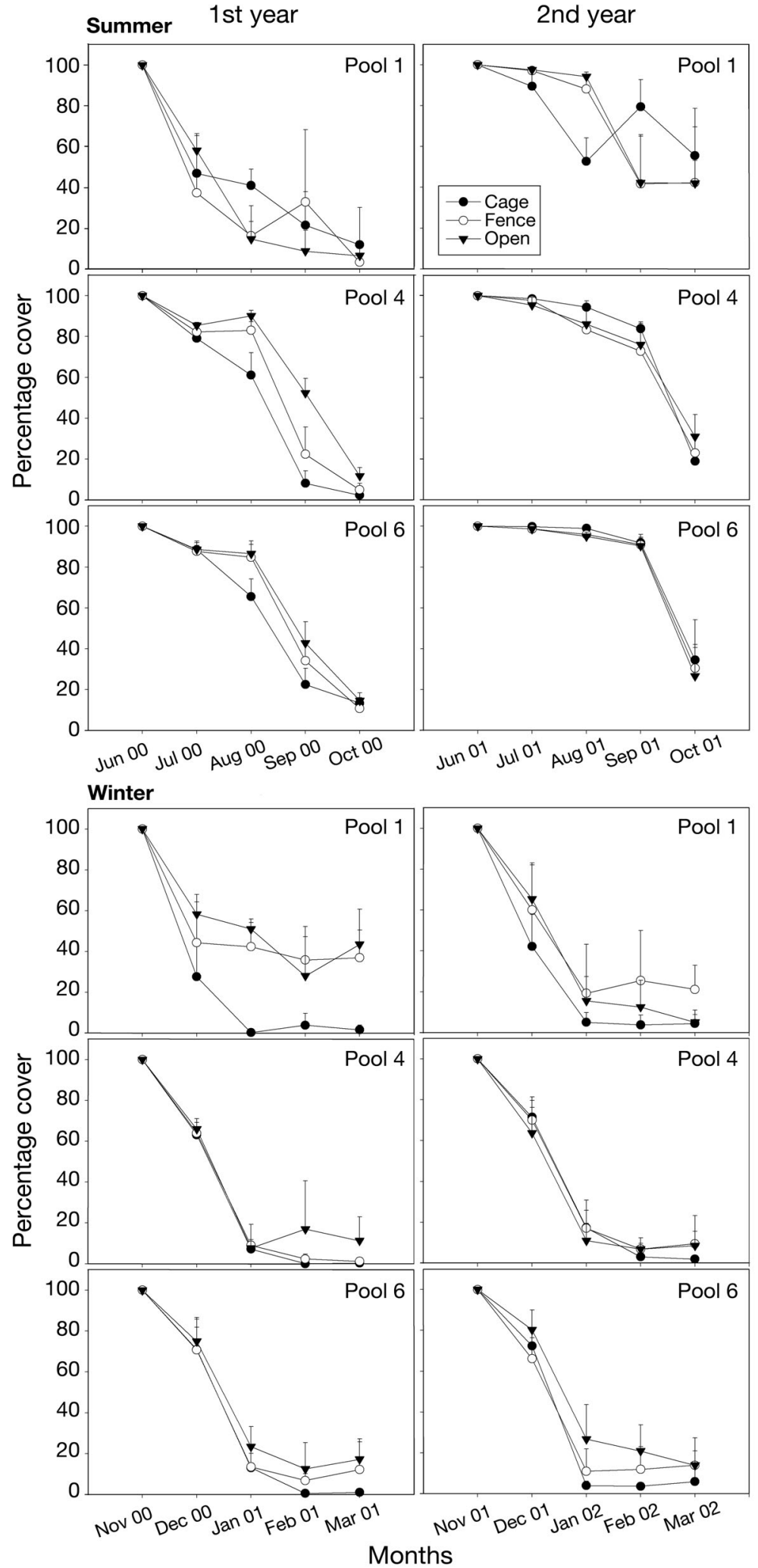

Fig. 1. Mean $(+\mathrm{SD}, \mathrm{n}=4)$ percentage cover of bare surface on new PVC plates among different treatments (Cage: grazer exclusion,-grazers; Fence: cage control, +grazers; Open: treatment control, +grazers) and pools (1,4 and 6) during summer (1st year: 2000; 2nd year: 2001) and winter (1st year: 2000-01; 2nd year: 2001-02) 

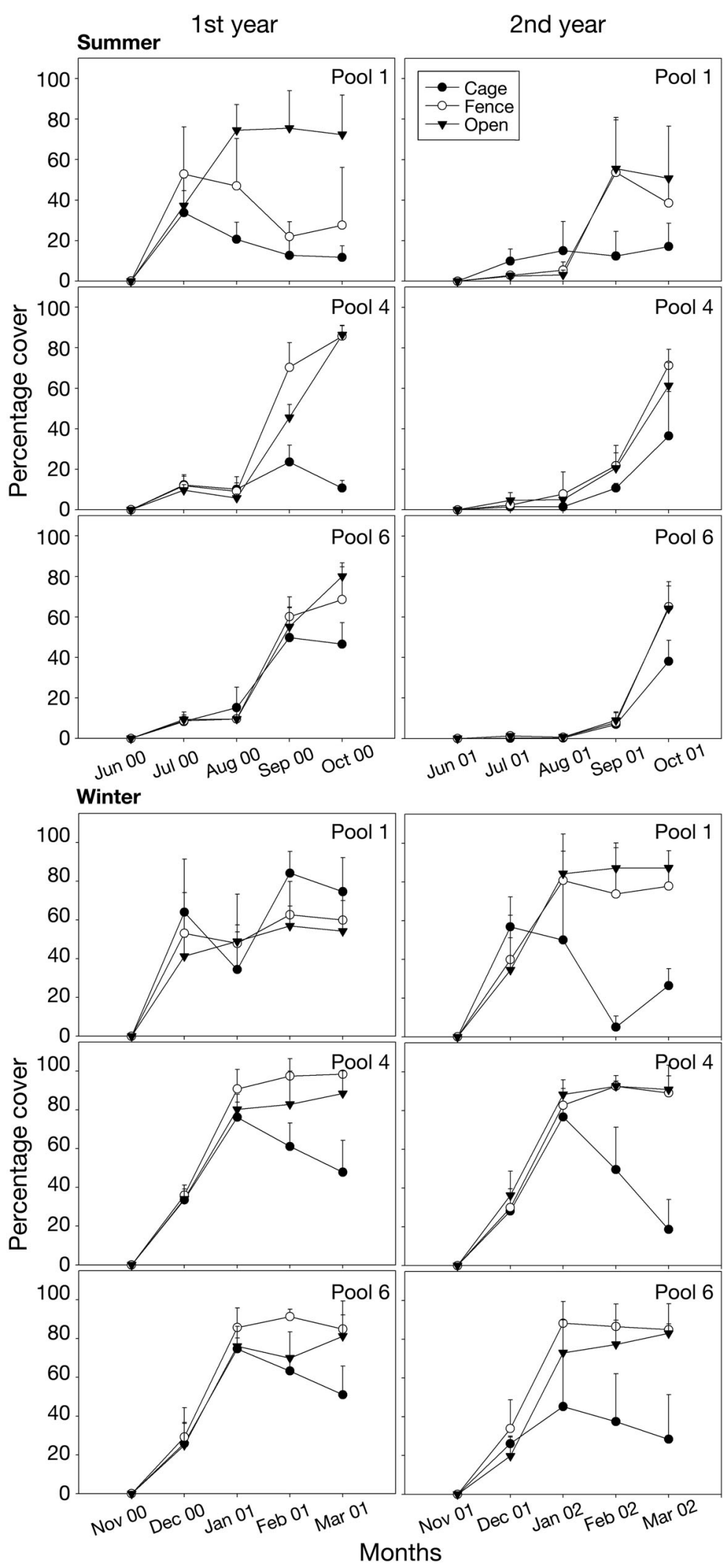

Fig. 2. Mean $(+\mathrm{SD}, \mathrm{n}=4)$ percentage cover of crustose coralline algae on new PVC plates among different treatments, pools, seasons and years. See Fig. 1 for abbreviations result of CCA settlement (Fig. 2, Tables 2 \& 3). In contrast, the crustose algae Ralfsia spp. and non-crustose macroalgae mostly developed on grazer-exclusion plates (Figs. 3 \& 4). CCA were the first crustose algae to colonize, followed by Ralfsia spp. (and also a very sparse, $<1 \%$, cover of green turfs and Hincksia mitchelliae) in summer (Fig. 3) and by non-crustose macroalgae in winter (Fig. 4). Sparse cover $(<1 \%)$ of sessile animals (mostly Spirorbis foraminosus and sparse Hydroides elegans, rock oysters Saccostrea cucullata and barnacles Balanus amphitrite) were also recorded.

Colonization extent. The extent of colonization by algae varied with pool, season and year (Table 2). Bare surface cover decreased faster in winter than summer in both years. Patterns were similar in both winters, whilst the summers varied, with a slower algal colonization period in the second than the first year (Fig. 1). Although overall trends were similar between pools, the timing and extent were variable (Fig. 1).

After $4 \mathrm{mo}$, higher bare surface cover was left on the plates in summer than winter, especially in grazer exclusions, in all pools. This pattern was only significant in the second year (Tables 2 \& 3, Fig. 1), whereas in the first year the bare surface cover was similar in summer and winter. Pool 1 was, however, an exception, where bare surface cover was higher in winter in the first year, especially in grazer-access treatments (Tables $2 \& 3$, Fig. 1).

Crustose coralline algae. Whilst there was a predictable, general pattern of CCA settlement in all pools, the rate of settlement and subsequent lateral growth varied with pool, season and year (Figs. 1 \& 2). Early settlement of CCA (the number of settlers after the first month) varied with treatment, pool, season and year and significant interactions between these factors (Table 2). CCA settlement rates were higher in winter than summer in both years (Table 3). Settlement rates between treatments were similar in both seasons and years, with the exception of the summer of the second year (Table 3).

The colonization (settlement and development) of CCA was higher in winter than summer in both years. CCA colonization was, however, variable between pools in both summer and winter of both years (Fig. 2). Colonization in the summer of the second year 
Table 2. F-ratios from ANOVA to investigate variation in percentage cover of bare surface, crustose coralline algae and number of coralline settlers on new PVC plates after 4 mo primary settlement between treatments (Tr), pools (Po), seasons (Se) and years (Ye). Percentage cover data were arcsine $(\mathrm{x} \%)$ transformed, and the number of coralline settlers were $\ln (\mathrm{x}+1)$ transformed. Cochran's test for homogeneity, $\mathrm{p}>0.05$. Values in parentheses are error mean squares. Significant differences are given in bold and indicated by asterisk(s): ${ }^{*} \mathrm{p}<$ $0.05,{ }^{* * *} \mathrm{p}<0.001$. See Table 3 for results of Student-Newman-Keuls (SNK) tests

\begin{tabular}{|c|c|c|c|c|c|}
\hline Source & df & $\begin{array}{c}\text { Bare } \\
\text { surface } \\
(70.45)\end{array}$ & $\begin{array}{c}\text { Number } \\
\text { of coralline } \\
\text { settlers } \\
(0.07)\end{array}$ & $\begin{array}{c}\text { Crustose } \\
\text { coralline } \\
\text { algae } \\
(99.19)\end{array}$ & $F$ vs: \\
\hline $\mathrm{Ye}$ & 1 & 88.66* & 0.04 & 2.37 & $\mathrm{Ye} \times \mathrm{Po}$ \\
\hline $\mathrm{Se}$ & 1 & - & - & - & No test \\
\hline Po & 2 & $13.97^{*}$ & 6.29 & 16.74 & $\mathrm{Ye} \times \mathrm{Po}$ \\
\hline $\operatorname{Tr}$ & 2 & - & - & - & No test \\
\hline $\mathrm{Ye} \times \mathrm{Se}$ & 1 & 4.37 & 0.41 & 0.87 & $\mathrm{Ye} \times \mathrm{Se} \times \mathrm{Po}$ \\
\hline $\mathrm{Ye} \times \mathrm{Po}$ & 2 & 0.42 & $8.33^{* * *}$ & 1.71 & Residual \\
\hline $\mathrm{Ye} \times \operatorname{Tr}$ & 2 & 5.52 & 0.47 & 0.88 & $\mathrm{Ye} \times \mathrm{Po} \times \operatorname{Tr}$ \\
\hline $\mathrm{Se} \times \mathrm{Po}$ & 2 & 1.13 & 0.51 & 3.84 & $\mathrm{Ye} \times \mathrm{Po} \times \mathrm{Tr}$ \\
\hline $\mathrm{Se} \times \operatorname{Tr}$ & 2 & - & - & - & No test \\
\hline $\mathrm{Po} \times \operatorname{Tr}$ & 4 & 1.05 & 5.53 & 8.83 & $\mathrm{Ye} \times \mathrm{Po} \times \mathrm{Tr}$ \\
\hline $\mathrm{Ye} \times \mathrm{Se} \times \mathrm{Po}$ & 2 & $12.85^{* * *}$ & $10.32^{* * *}$ & 0.41 & Residual \\
\hline $\mathrm{Ye} \times \mathrm{Se} \times \mathrm{Tr}$ & 2 & 1.59 & 0.17 & $10.85^{*}$ & $\mathrm{Ye} \times \mathrm{Se} \times \mathrm{Po} \times \operatorname{Tr}$ \\
\hline $\mathrm{Ye} \times \mathrm{Po} \times \operatorname{Tr}$ & 4 & 1.01 & 1.65 & $3.03^{*}$ & Residual \\
\hline $\mathrm{Se} \times \mathrm{Po} \times \operatorname{Tr}$ & 4 & 3.48 & 1.29 & 2.52 & $\mathrm{Ye} \times \mathrm{Se} \times \mathrm{Po} \times \operatorname{Tr}$ \\
\hline $\mathrm{Ye} \times \mathrm{Se} \times \mathrm{Po} \times \operatorname{Tr}$ & 4 & 0.86 & $3.45^{*}$ & 1.66 & Residual \\
\hline Residual & 108 & & & & \\
\hline
\end{tabular}

was, in general, slower than that in the first year (Fig. 2). After $4 \mathrm{mo}$, in both seasons and years, CCA dominated both open and fence treatments. Percentage cover varied with pools and seasons/ years, in addition to the treatment effect (Table 2) being, in general, higher in grazer-access treatments than exclusions (Table 3, Fig. 2). Bleached coralline algae occurred in all pools in August 2000 and October 2001 (Fig. 3).

Non-coralline algae. Ralfsia spp. showed a relatively predictable settlement pattern in all pools, but the rate and cover varied with treatment, pool and year. Both the settlement rate and cover of Ralfsia in all pools were much higher in summer than winter. In summer of the first year, Ralfsia was abundant in grazer exclusions, but not in all pools (Fig. 3). In the second year, however, the overall settlement rate and cover were much lower in all pools (Fig. 3).

After $4 \mathrm{mo}$, in all pools, cover of Ralfsia in the first year was higher than in the second year (Fig. 3). Ralfsia was
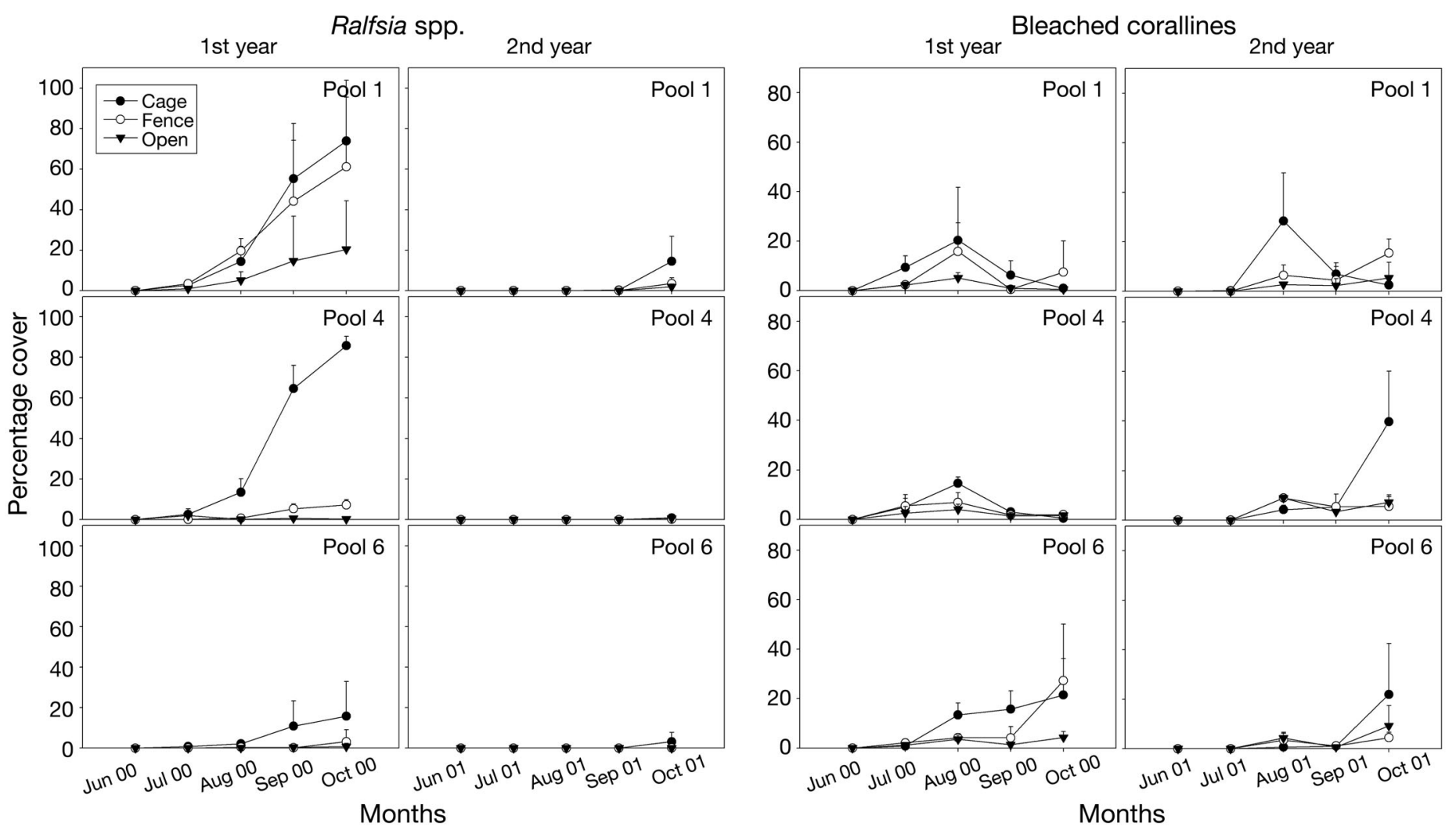

Fig. 3. Mean $(+\mathrm{SD}, \mathrm{n}=4)$ percentage cover of Ralfsia spp. and bleached corallines on new PVC plates in summer among different treatments, pools and years. See Fig. 1 for abbreviations. Note scales of y-axis are different 
Table 3. SNK tests to investigate significant fixed factors from ANOVA presented in Table 2 (see Table 2 for abbreviations)

\begin{tabular}{|c|c|c|c|}
\hline \multicolumn{2}{|c|}{ SNK tests } & 1st year & 2nd year \\
\hline \multicolumn{4}{|c|}{ Bare surface: } \\
\hline Pool 1 & & Summer $<$ Winter & Summer $>$ Winter \\
\hline Pool 4 & & Summer $=$ Winter & Summer $>$ Winter \\
\hline Pool 6 & & Summer $=$ Winter & Summer $>$ Winter \\
\hline \multicolumn{4}{|c|}{ Number of coralline settlers: } \\
\hline \multicolumn{4}{|c|}{ Ye $\times$ Se $\times$ Po $\times \operatorname{Tr}:$} \\
\hline \multirow[t]{3}{*}{ Summer } & Pool 1 & Cage $=$ Fence $=$ Open & Cage $>$ Fence $=$ Open \\
\hline & Pool 4 & Cage $=$ Fence $=$ Open & Cage $<$ Fence $=$ Open \\
\hline & Pool 6 & Cage $=$ Fence $=$ Open & Cage $<$ Fence $=$ Open \\
\hline \multirow[t]{3}{*}{ Winter } & Pool 1 & Cage $=$ Fence $=$ Open & Cage $=$ Fence $=$ Open \\
\hline & Pool 4 & Cage $=$ Fence $=$ Open & Cage $=$ Fence $=$ Open \\
\hline & Pool 6 & Cage $=$ Fence $=$ Open & Cage $=$ Fence $=$ Open \\
\hline \multirow[t]{3}{*}{ Pool 1} & Cage & Summer $<$ Winter & Summer $<$ Winter \\
\hline & Fence & Summer $<$ Winter & Summer $<$ Winter \\
\hline & Open & Summer $<$ Winter & Summer $<$ Winter \\
\hline \multirow[t]{3}{*}{ Pool 4} & Cage & Summer $<$ Winter & Summer $<$ Winter \\
\hline & Fence & Summer $<$ Winter & Summer $<$ Winter \\
\hline & Open & Summer $<$ Winter & Summer $<$ Winter \\
\hline \multirow[t]{3}{*}{ Pool 6} & Cage & Summer $<$ Winter & Summer $<$ Winter \\
\hline & Fence & Summer $<$ Winter & Summer $<$ Winter \\
\hline & Open & Summer $<$ Winter & Summer $<$ Winter \\
\hline \multicolumn{4}{|c|}{ Crustose coralline algae: } \\
\hline \multicolumn{4}{|c|}{ Ye $\times$ Po $\times$ Tr: } \\
\hline \multicolumn{2}{|l|}{ Pool 1} & Cage $=$ Fence $<$ Open & Cage $<$ Fence $=$ Open \\
\hline \multicolumn{2}{|l|}{ Pool 4} & Cage $<$ Fence $=$ Open & Cage $<$ Fence $=$ Open \\
\hline \multicolumn{2}{|l|}{ Pool 6} & Cage $<$ Fence $=$ Open & Cage $<$ Fence $=$ Open \\
\hline \multicolumn{4}{|c|}{ Ye $\times$ Se $\times$ Tr: } \\
\hline \multicolumn{2}{|l|}{ Cage } & Summer $<$ Winter & Summer = Winter \\
\hline \multicolumn{2}{|l|}{ Fence } & Summer $<$ Winter & Summer $<$ Winter \\
\hline \multicolumn{2}{|l|}{ Open } & Summer = Winter & Summer $<$ Winter \\
\hline \multicolumn{2}{|l|}{ Summer } & Cage $<$ Fence $<$ Open & Cage Open Fence \\
\hline \multicolumn{2}{|l|}{ Winter } & Cage $=$ Fence $=$ Open & Cage $\overline{<\text { Fence }=\text { Open }}$ \\
\hline
\end{tabular}

usually most abundant in grazer exclusions, especially during the first summer (Table 4, Fig. 3). The effect of grazer exclusion did, however, vary with pools and also with year. In the first year, Ralfsia cover, for example, was higher in exclusion than in grazer-access treatments in Pool 4, while in Pool 6 delayed settlement resulted in a relatively lower cover in exclusions (Fig. 3). In addition, there was unexpectedly high Ralfsia cover in the fence treatment in Pool 1 (but not in Pools 4 and 6 ) in summer of the first year (Table 4, Fig. 3). In the second year, however, cover in all pools was much lower than in the first year and grazer exclusion only had an effect in Pool 1 (Table 4).

There was a strong seasonal trend in non-crustose macroalgal settlement and growth, as most were only found in winter, but cover varied with treatment, pool and year (Table 4). Non-crustose macroalgae were almost only found in grazer exclusions in winter in both years, although patterns and species compositions varied between pools. In Pools 4 and 6, Hincksia mit- chelliae rose to ca. $10 \%$ cover after 3 mo in Year 1 and to ca. 20-30\% cover after 3 mo in Year 2. Green turfs peaked after $4 \mathrm{mo}$ in both years (30 to $40 \%$ cover), and Ulva spp. rose to $5-15 \%$ cover in Year 1, but was absent in Year 2. Colpomenia sinuosa was virtually the only non-crustose alga to appear in Pool 1 and peaked at 60 to $70 \%$ cover after 2 mo in Year 1 and after 2 to $4 \mathrm{mo}$ in Year 2, before declining. Once these erect macroalgae settled, they grew quickly, and their increase was linked with a reduction in visible CCA after 3 mo (Figs. 2 \& 4). CCA, however, persisted under the $C$. sinuosa, and their percentage cover increased once the $C$. sinuosa died. In both years, there was a significant grazer-exclusion effect in all the pools (Table 4), with erect algae being confined to grazer exclusions apart from the appearance of $C$. sinuosa in the fence treatment in Year 1 and in open treatments in Pool 1 in Year 2 (Fig. 4).

Grazing pressure in primary settlement pools $(\mathbf{1}, 4$ and 6). Graze marks of the gastropods Chlorostoma argyrostoma, Lunella coronata and Nerita albicilla were abundant in all pools. Individual species showed different patterns that were consistent in all pools. Grazing pressure of L. coronata, for example, was similar in both summer and winter, whilst $N$. albicilla and $C$. argyrostoma exhibited seasonal variation. In summer, grazing pressure of $N$. albicilla and $L$. coronata was greater than that of $C$. argyrostoma in all pools (Fig. 5). In winter, the grazing pressure of C. argyrostoma increased, whilst that of $N$. albicilla was dramatically reduced.

Grazing pressure of the sea urchin Anthocidaris crassispina was variable between pools, especially in winter, with urchins removing between 9 and $78 \%$ of the CCA in Pool 1, compared to $6-26 \%$ in Pools 4 and 6. Sea urchins, in general, grazed patchily, both in space (large SD; Fig. 6) and time (large differences between months, e.g. in Pool 1; Fig. 6).

\section{Persistence of crustose coralline algae in space and time}

Before treatment installation, CCA dominated the surface of all plates (>70\%; Fig. 7) and resembled the surrounding assemblages (Wai 2004). After treatment installation, a predictable pattern of secondary settlement and development of algal assemblages was recorded. The persistence of CCA and final algal as- 


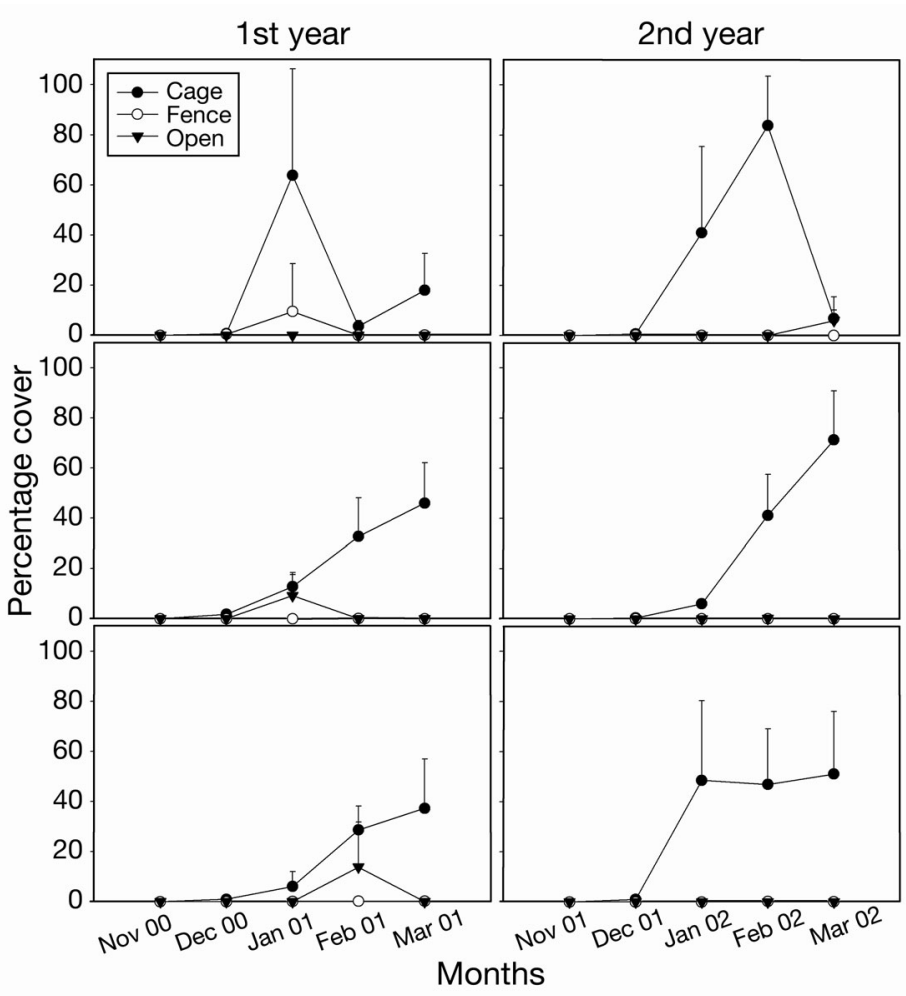

Fig. 4. Mean $(+\mathrm{SD}, \mathrm{n}=4)$ percentage cover of non-crustose macroalgae on new PVC plates in winter among different treatments, pools and years. See Fig. 1 for abbreviations
(Fig. 7). In contrast, bare surface cover in grazer exclusions continued to increase, except in Pool 8, where there was an increase in CCA cover (Fig. 7). After the heavy summer bleaching and mortality of $\mathrm{CCA}$, the rate of release of bare surface was much slower in grazer-exclusion than grazer-access treatments and was consistent in all pools (Fig. 7).

In winter, CCA cover gradually decreased after treatment installation, the extent of which varied between treatments, but was greater in grazer exclusions and was coupled with an increase in bare surface in the open and fence treatments (Fig. 7) and cover of non-crustose macroalgae (mainly green turfs; Figs. 7 \& 9).

After 4 mo, CCA showed significant interactions between pool and season, with greater cover in summer than winter in some, but not all, pools (Table 5). Cover decreased after 4 mo post-treatment installation, reaching lower levels in summer than winter in Pools 8 and 9 (Fig. 7). Bleached CCA also showed a significant $\mathrm{Se} \times$ Po interaction after $4 \mathrm{mo}$, with lower cover in summer than winter in all pools (Table 5). Bleaching was most obvious in exclusions, where it peaked early in summer $(\sim 60 \%$ cover $)$, but increased progres- semblage development, however, varied spatially and temporally and were strongly affected by grazing in all pools.

Crustose coralline algae, bleached corallines and bare surface. In summer, there was a heavy mortality of CCA from May 2002 to July 2002. In July 2002, only 20 to $30 \%$ CCA cover remained (Fig. 7) and this was consistent for all treatments and in all pools. The extent of subsequent re-colonization of CCA after July 2002, however, varied with treatments and pools. Cover gradually increased after August 2002 in all grazer-access treatments, but there was little recovery in exclusion treatments. CCA were the first encrusting algae to colonize newly released PVC surfaces following the summer die-off, followed by sparse Ralfsia cover (<1\%; Fig. 8) and green spores $(<5 \%)$ in October 2002.

The increase in cover of CCA in grazer-access treatments was coupled with a reduction in bare surface after August 2002 or September 2002
Table 4. F-ratios and SNK tests from ANOVA to investigate variation in percentage cover of Ralfsia spp. and non-crustose macroalgae on new PVC plates after 4 mo primary settlement between treatments (Tr), pools (Po), seasons (Se) and years (Ye). Data were $\ln (x+1)$ and arcsine $(x \%)$ transformed, respectively. Cochran's test for homogeneity, $p>0.05$. Values in parentheses are error mean squares. Significant differences are given in bold and indicated by asterisk(s): ${ }^{*} \mathrm{p}<0.05,{ }^{* *} \mathrm{p}<0.01$

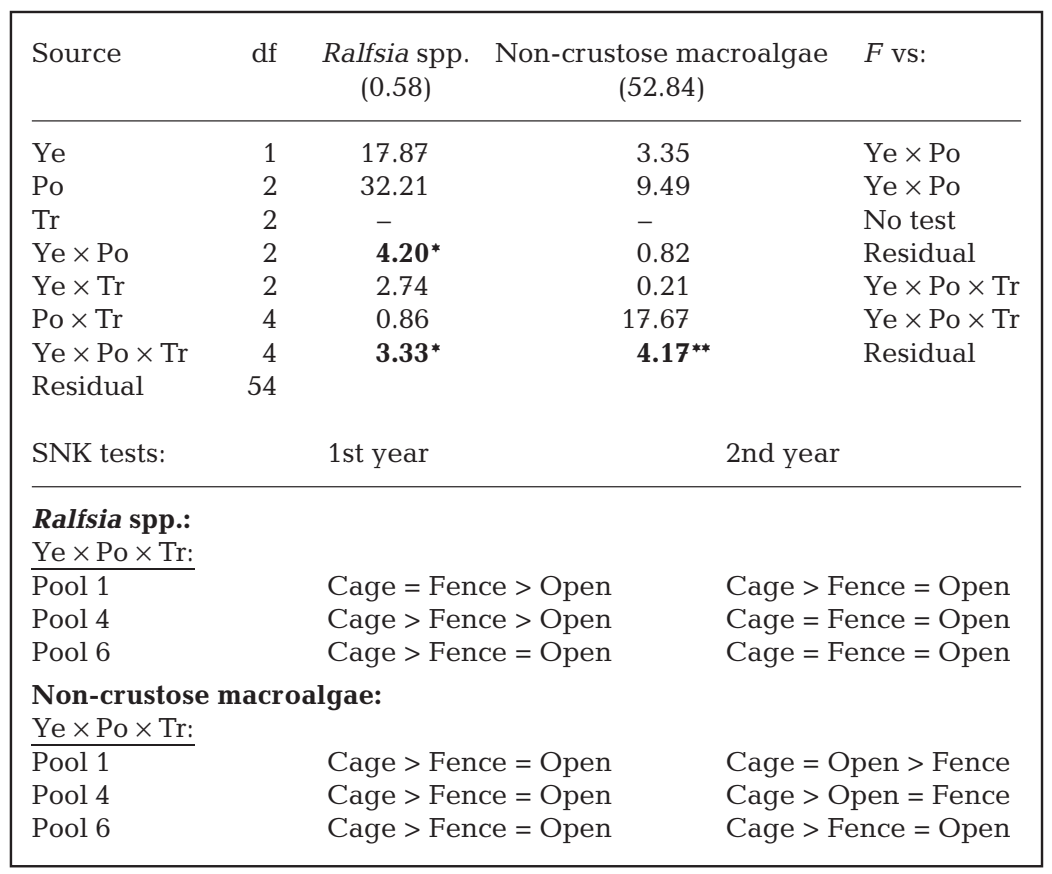


sively in winter (to 30-60\% cover; Fig. 8).

Bare surface cover showed significant interactions ( $\mathrm{Se} \times \operatorname{Tr}$ and $\mathrm{Se} \times \mathrm{Po}$; Table 5), with greater cover in summer than winter in grazer exclusions, but similar cover in summer and winter in grazer-access treatments (Table 5). At the end of summer, bare surface cover was higher in exclusions than in grazer-access treatments, but this was not the case at the end of winter (Table 5).

Non-coralline algae. Low cover $(<5 \%)$ of Ralfsia spp. was found in both summer and winter (Fig. 8). Non-crustose macroalgal cover was virtually limited to winter in all pools. A large proportion (90 to 100\%) of the non-crustose macroalgae were green turfs (mostly Enteromorpha compressa, but also Chaetomorpha antennina and Cladophora delicatula); the rest (2 to 8\%) comprised the brown alga Hincksia mitchelliae. Only the green turfs were able to overgrow the live coralline crusts (Wai pers. obs.). H. mitchelliae only invaded at a

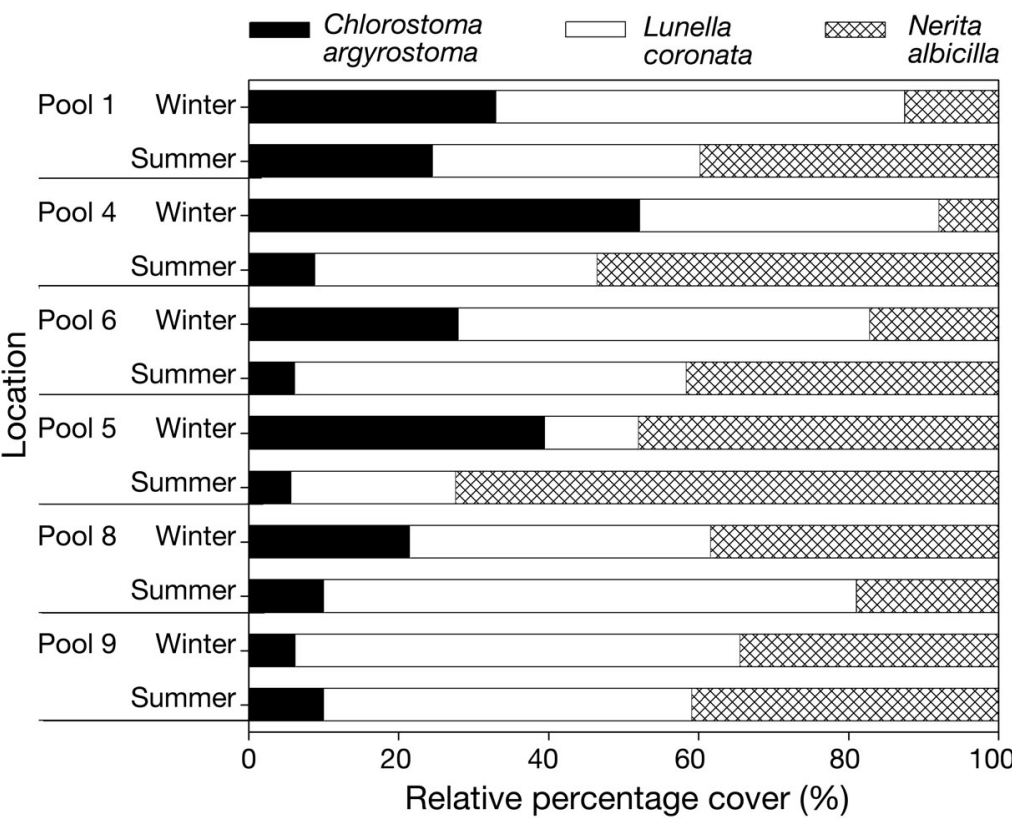

Fig. 5. Chlorostoma argyrostoma, Lunella coronata and Nerita albicilla. Relative percentage cover of graze marks (\%; $\mathrm{n}=36$ for Pools 1,4 and 6 ; $\mathrm{n}=24$ for Pools 5, 8 and 9) of the most abundant gastropod grazers on wax plates in different pools, during summer and winter

later stage, after new substrate was released due to coralline bleaching. These macroalgae were only occasionally recorded in summer, and the percentage cover was very low $(<5 \%)$.

The pattern of macroalgal settlement was predictable in all pools, although the extent varied with treatment and pool. Erect macroalgae were only able to grow in grazer exclusions in winter, although sparse new settlement and recruitment $(<2 \%)$ were found on all plates in some pools prior to treatment installation (i.e. December 2001; Fig. 9).

After $4 \mathrm{mo}$, macroalgae cover in exclusions was greater than in grazer-access treatments (2-way ANOVA, treatment effect, $F_{2,27}, \mathrm{p}=0.002$, all other terms p $>0.05$; followed by SNK tests, Cage $>$ Fence $=$ Open treatments; Fig. 9), although settlement patterns varied between pools. Macroalgae (i.e. green turfs) grew quickly, although cover varied between pools, with peak cover occurring at different times (Fig. 9). The increase in cover of macroalgae in the grazer exclusions was usually coupled with a reduction in CCA cover after 1 mo (i.e. January 2002; Figs. 7 \& 9). Green spores were found in both summer and winter, mostly at the latter stages of the experiments, but only in grazer exclusions, where they reached 1 to $9 \%$ cover.

Grazing pressure in the persistence experiment pools $(5,8$ and 9). Wax plates recorded abundant graze marks of Nerita albicilla, Lunella coronata and Chlorostoma argyrostoma in all pools. In both summer and winter, grazing pressure of $N$. albicilla and L. coro-

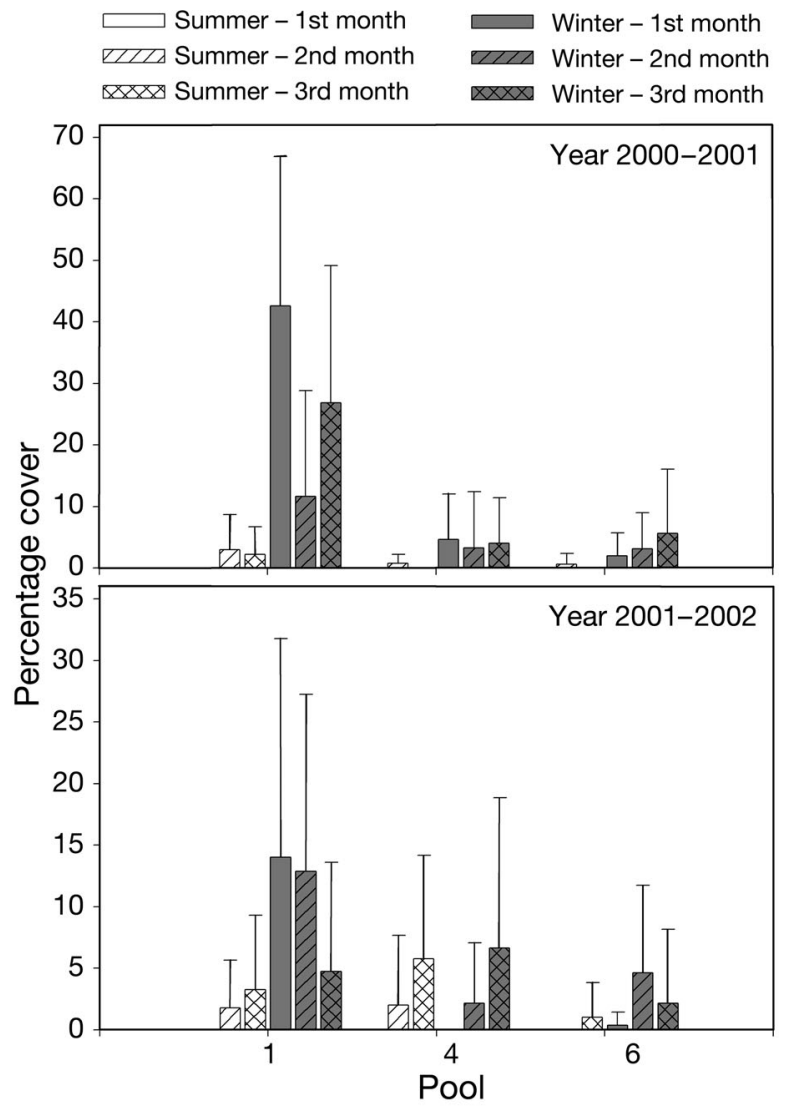

Fig. 6. Anthocidaris crassispina. Mean $(+\mathrm{SD}, \mathrm{n}=8)$ percentage cover of graze marks by sea urchins on PVC plates. Note scales of $y$-axis are different 

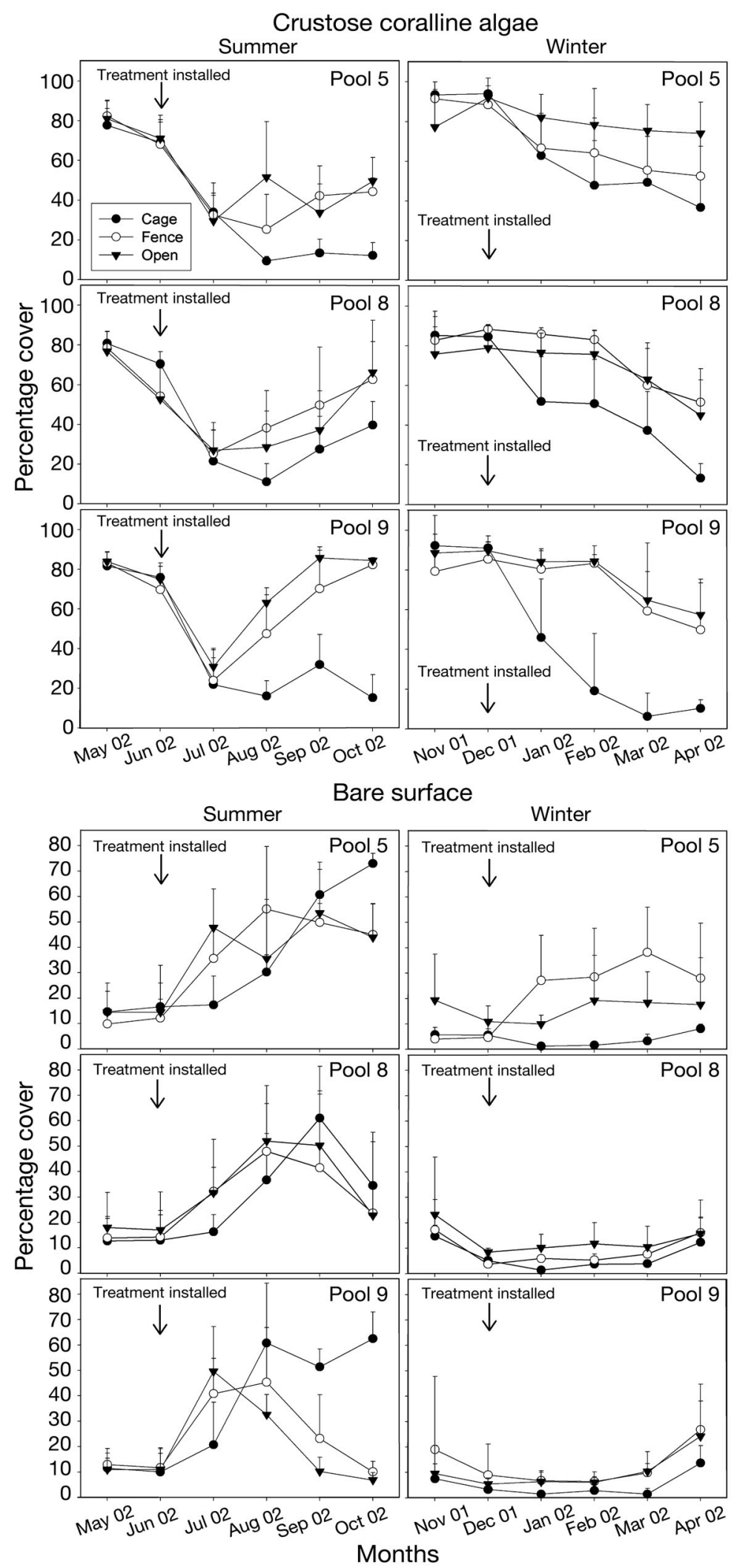

Fig. 7. Mean $(+\mathrm{SD}, \mathrm{n}=4)$ percentage cover of crustose coralline algae and bare surface on CCA-colonized PVC plates among different treatments (Cage: grazer exclusion, -grazers; Fence: cage control, +grazers; Open: treatment control, +grazers) and pools (5,8 and 9), during summer and winter Note scales of y-axis are different nata was relatively greater than that of $C$. argyrostoma in all pools (with the exception of Pool 5 in winter; Fig. 5). Although grazing pressure of individual species varied with season, there was no clear pattern. Sea urchin grazing trails were only occasionally found on grazer-access plates (see Wai 2004).

\section{DISCUSSION}

\section{Factors affecting algal settlement patterns and persistence in rock pools}

CCA dominated all low-shore rock pools during both summer and winter, but only in the presence of natural herbivore densities. Once a newly created bare surface was available, CCA were always the first algal crusts to colonize (also see Coleman 2003). The persistence of CCA was, however, strongly affected by physical (i.e. heat stress) and biological (i.e. herbivore-induced/grazing) disturbance and the interaction between these factors. Such disturbances play an important role by frequently renewing rock space, in the form of discrete bare patches within the corallines (see Paine \& Levin 1981, Sousa 1985), resulting in patches of CCA at various stages of development (i.e. a mosaic of different 'ages'; Sousa 1985, Benedetti-Cecchi \& Cinelli 1994). In addition, grazer-mediated disturbance eliminates competitively dominant epiphytic species (Paine 1984), such as green algal turfs, allowing a mosaic of coexisting, resilient coralline species to persist in the pools.

\section{Physical disturbance - heat stress during summer}

Many species of algae in rock pools, especially CCA, bleach when subject to heat stress (Dethier 1984). Heat stress, resulting from prolonged, daytime, spring low tides in summer (pool water temperatures $>30^{\circ} \mathrm{C}$, especially the top $30 \mathrm{~cm}$ ), was an important factor affecting coralline persistence. Mass mortality and subsequent bleaching of coralline algae, especially individuals that settled in the previous winter (Wai 2004), were common in all pools during the onset of summer ( June). 
The rate and extent of coralline recovery, however, varied between pools, indicating differences in rates of settlement and recruitment between pools and/or differences in the extent and scale of disturbance (e.g. grazing pressure, thermal stress; Chapman \& Underwood 1998). Between-pool differences in the timing and rate of settlement may reflect highly localized sources of propagules, suggesting that small spatial scale variation is important in determining pool assemblages (see Chapman \& Underwood 1998).

In general, the turnover time needed for CCA in summer (i.e. recovery or re-colonization and return to initial cover, i.e. $\sim 70 \%$, after disturbance induced by thermal stress) was variable between pools (ranging from 2 to $>3 \mathrm{mo}$ ) and with size of disturbed patches. Maximum recovery rate was estimated to be $\sim 17 \%$ cover $\mathrm{mo}^{-1}$ or $23.8 \mathrm{~cm}^{2} \mathrm{mo}^{-1}$, which is sufficient to ensure the dominance and persistence of CCA in these rock pools (also see Adey \& Vassar 1975, Johansen 1981).

\section{Herbivore-induced disturbance in low-shore rock pools}

During the early settlement stage, although CCA settlers were observed on new surfaces in either the presence or absence of macrograzers, CCA could only develop and dominate the surfaces in the presence of macrograzers. When macrograzers were excluded, the later colonists, particularly non-crustose macroalgae in winter and Ralfsia spp. in summer, overgrew the CCA.

Sea urchins are the dominant grazers, in terms of their size and excavating ability, in many intertidal and subtidal habitats (see Lawrence 1975, Ayling 1981, Steneck \& Watling 1982). In this study, although the density of sea urchins in some of the pools and their corresponding grazing frequency were low, their excavating ability and potential impact was relatively high as compared to molluscan grazers (Spencer 1992). Sea urchin grazing trails were often found (Wai 2004) and once they accessed substrates, they created new patches of bare space in between the developed CCA. This kind of localized disturbance is common on rocky substrates, with discrete patches of newly created bare surfaces between existing
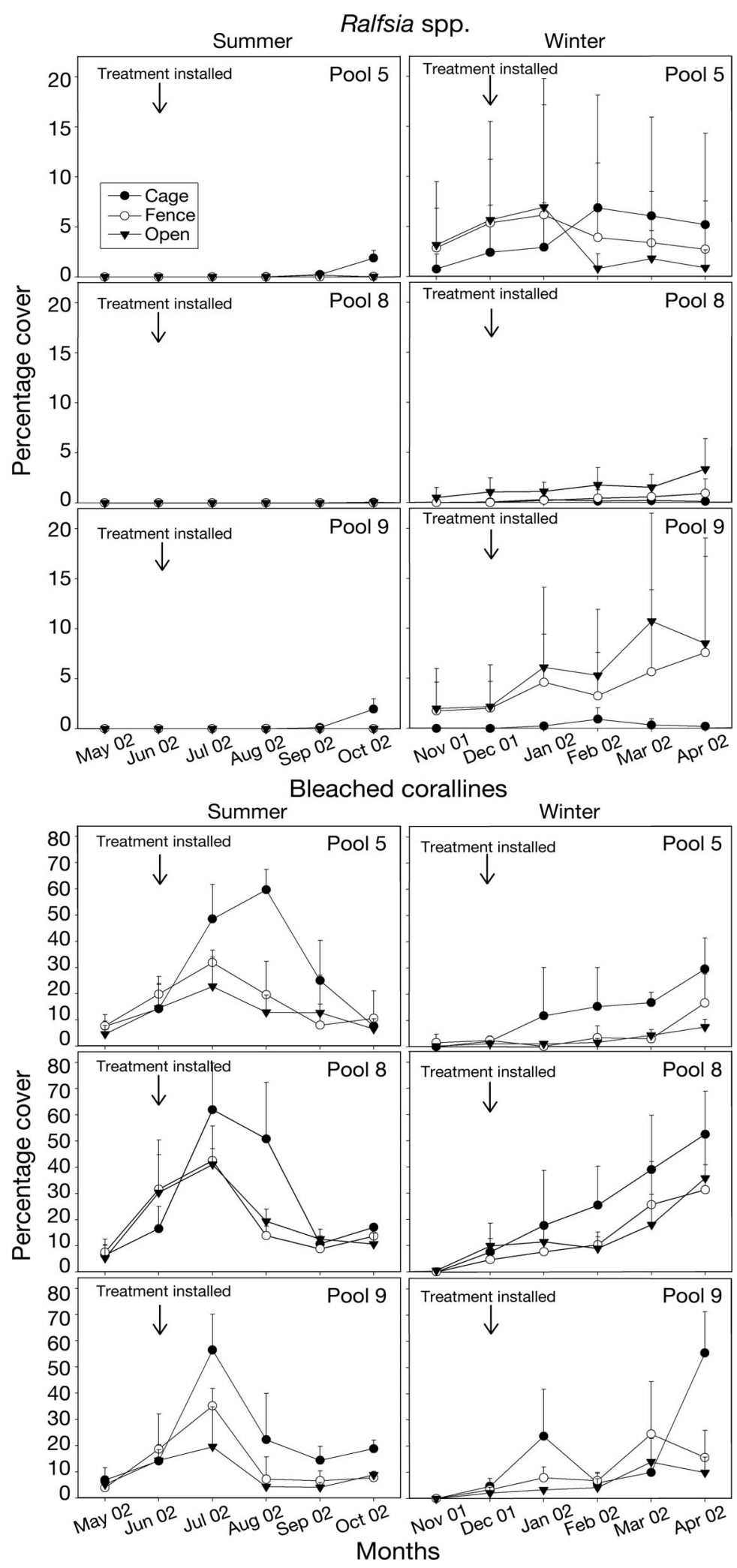

Fig. 8. Mean (+SD, $\mathrm{n}=4$ ) percentage cover of Ralfsia spp. and bleached corallines on CCA-colonized PVC plates among different treatments and pools, during summer and winter. See Fig. 7 for abbreviations. Note scales of y-axis vary 


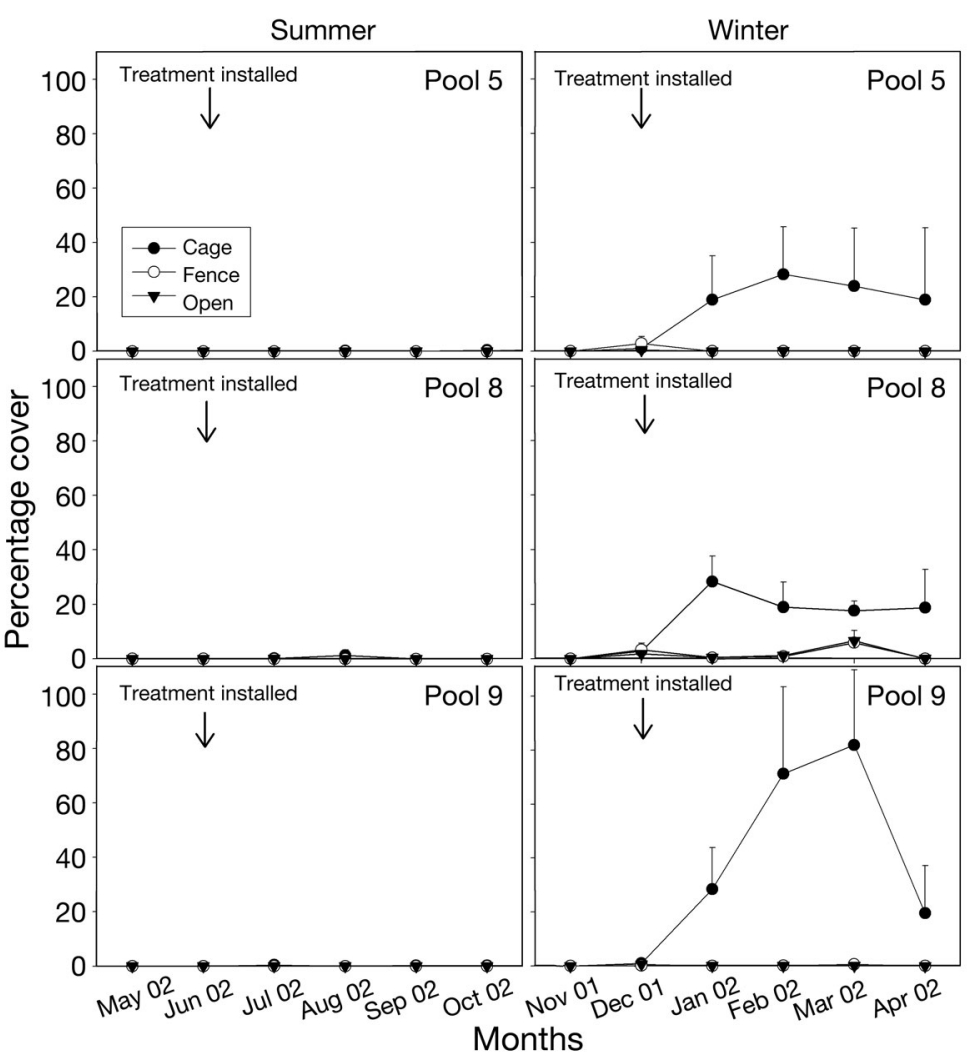

Fig. 9. Mean $(+\mathrm{SD}, \mathrm{n}=4)$ percentage cover of non-crustose macroalgae on CCA-colonized PVC plates among different treatments and pools, during summer and winter. See Fig. 7 for abbreviations

assemblages of different sizes and ages (Paine \& Levin 1981, Sousa 1984, 1985). Such patches are important to the success of primary colonists, such as coralline algae, as these species perform lateral vegetative growth and space is often a limiting resource (Sousa 1985, Steneck 1986).

Molluscan macrograzers were common in the pools and were also able to remove algal biomass, and thus act as a biotic disturbance (Steneck \& Watling 1982, Wai \& Williams 2006). Although the excavating ability of individual molluscan grazers is much more limited than that of sea urchins (Spencer 1992), their combined grazing pressure, in terms of disturbance frequency, was much higher than that of sea urchins (Wai \& Williams 2006). These molluscan grazers may play a different role in these algal assemblages, by exerting indirect effects on the crusts, removing epiphytes or new recruits of more competitive species (e.g. Ralfsia spp., filamentous green turfs and erect macroalgae) or fouling materials (e.g. sediments; Steneck et al. 1991, Hawkins et al. 1992). Grazing may also help to release propagules from the conceptacles of coralline algae and to enhance the availability of new recruits, facilitate subsequent settlement, or stimulate productivity (Kaehler \& Froneman 1999, Wai \& Williams 2005). Such algae-grazer interactions sug- gest a positive relationship (i.e. mutualism) between grazers and encrusting algae and are thought to be important for the success of coralline crusts (Steneck 1986).

Macroalgae overgrew the CCA rapidly in the absence of grazers. A variety of macroalgal taxa (including Hincksia mitchelliae, Enteromorpha compressa, Ulva spp., Colpomenia sinuosa and Gelidium pusillum) overgrew newly settled CCA, whereas green turfs (mostly E. compressa) were more readily able to overgrow established CCA. The timing and settlement rate of these erect macroalgae were, however, variable between pools. These differences may be due to variability in availability of algal propagules in different pools and/or at different times, since even a small difference in the timing of release of new substrate may determine which algae can colonize the substrate (Figueiredo et al. 1997, Chapman \& Underwood 1998).

Deposition and accumulation of sediments occurred amongst the turfs (see also Airoldi \& Virgilio 1998), which may also have had a negative effect on the persistence and survival of the CCA (Fabricius \& De'ath 2001). Although some studies have shown that CCA can persist underneath turfs (Airoldi 2000), in the present study, most corallines were not able to persist underneath the green turfs, although they were able to persist for longer under $C$. sinuosa.

\section{Spatial and temporal variation}

Settlement and cover of both CCA and erect macroalgae varied between pools and seasons. All pools were dominated by CCA, but each pool showed its own specific algal settlement rates, highlighting individual variability and the difficulties in generalizing about the exact processes important in each pool (Dethier 1984, Underwood \& Jernakoff 1984). The pool variation in settlement rates and species compositions was probably related to the physical characteristics of individual pools. The lower position of Pool 1, for example, may favour faster rates of algal settlement for CCA and Colpomenia sinuosa.

Variation in the supply of algal propagules may explain the patterns of recruitment of algae, both spatially (Andrew \& Viejo 1998) and temporally (Sousa 1985, Benedetti-Cecchi \& Cinelli 1994). Macroalgal distribution and abundance in Hong Kong show strong seasonal variation (Hodgkiss 1984, Williams 1993, Kaehler \& Williams 1996). The persistence of CCA (Wai 2004), 
Table 5. F-ratios from ANOVA to investigate change in percentage cover (before and after 4 mo treatment installation) of crustose coralline algae, bleached coralline algae and bare surface on CCA-colonized PVC plates after 4 mo between treatments (Tr), pools (Po), seasons (Se) and years (Ye). Data were not transformed. Cochran's test for homogeneity, $\mathrm{p}>0.05$. Values in parentheses are error mean squares. Significant differences are given in bold and indicated by asterisk(s): ${ }^{*} \mathrm{p}<0.05,{ }^{* *} \mathrm{p}<0.01,{ }^{* * *} \mathrm{p}<0.001$

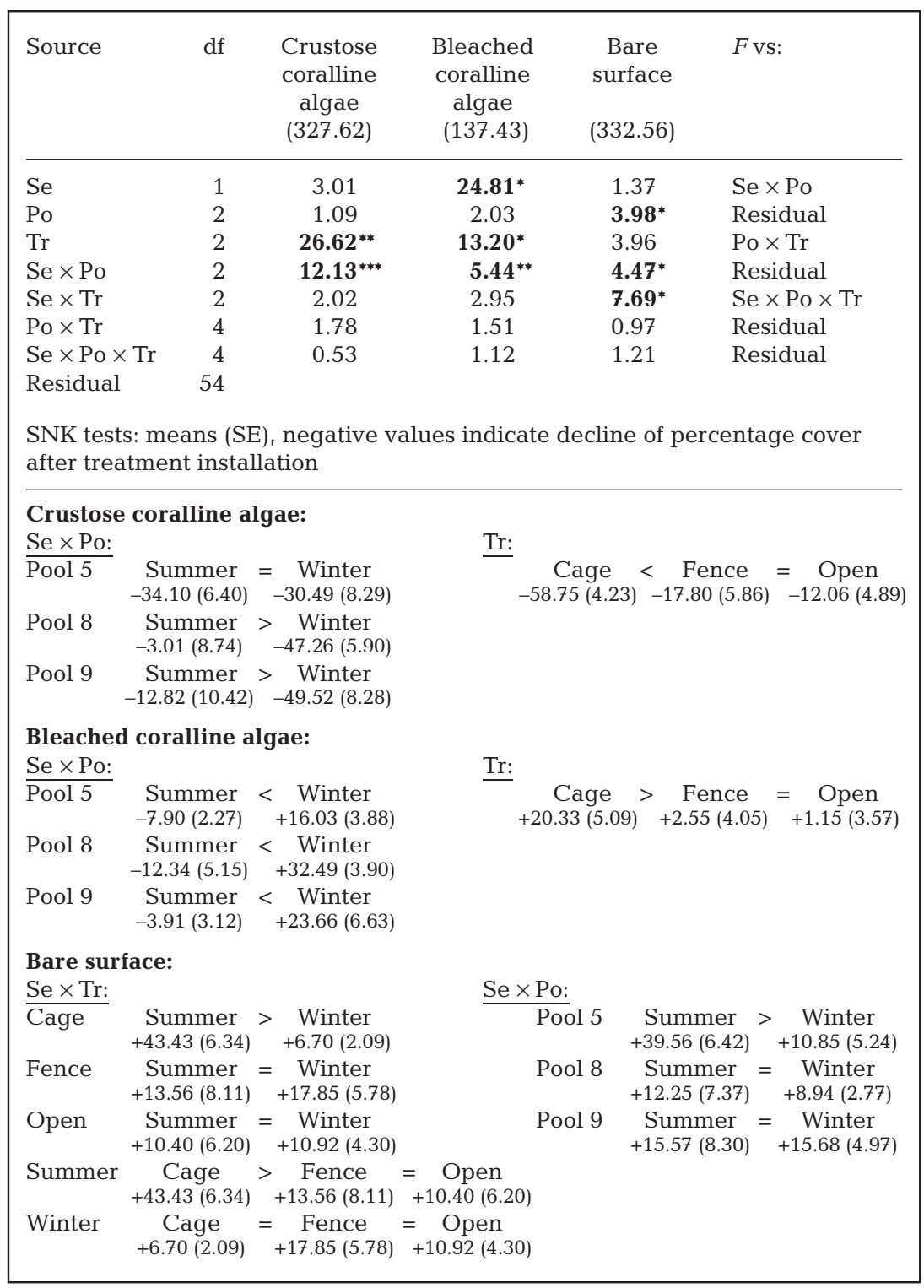

summer. Bleached corallines occurred in all pools in summer, probably due to increased pool water temperatures during daytime, spring low tides (max. emersion period $>10 \mathrm{~h}$ during calm days). All the bleached corallines died and sloughed off the substrate. In addition to heat stress, pulses of lower salinities $(<26 \%)$ in summer after heavy rain during low tide can also be a potential cause of bleaching (also see Morritt \& Williams 2000). The salinity of open seawater recorded during summer $(<28 \%)$ was generally lower than in winter (>32\%o) and, in 2001, salinities $<25 \%$ were recorded, which may explain the low settlement rate of all algae, especially Ralfsia spp.

The increase of Ralfsia in summer, but not in winter, indicated summer was favorable for its growth or reproduction. Ralfsia settlement, however, varied between pools and years. Other erect macroalgae like Enteromorpha compressa, Ulva spp. and Colpomenia sinuosa are ephemeral and only able to reproduce/ grow rapidly in winter. This strategy of fast growth is important for the success of these species, as, once they settle and escape from grazing, they grow to a large size and occupy a substantial area of substrate within a short time (e.g. C. sinuosa). This rapid growth also explains why some macroalgae, such as $C$. sinuosa, were also found in open/fence treatments (i.e. grazer-access substrates) in winter, as they can achieve the necessary size to escape from molluscan grazers. however, implies that seasonal variation does not play such an important role in the low-shore rock pools.

CCA did, however, show seasonal differences in settlement rate and in the species recorded (also see Hall-Spencer 1994). In winter, corallines colonized bare surfaces and grew at a faster rate than in summer $(\sim 1$ to $2 \mathrm{~mm} \mathrm{mo}^{-1}$; Wai 2004, especially Hydrolithon samoënse and Neogoniolithon misakiense), probably as a result of the cooler water temperature (mean $<20^{\circ} \mathrm{C}$ ). Patches that settled in winter were often bleached during early

\section{Characteristics of crustose coralline algae in low-shore rock pools}

The dominance of CCA in pools suggests that these slow-growing, competitively inferior, but grazer-resistant algae are better adapted to these pool habitats than other algae. The production of non-mobile propagules, which is unique to the Rhodophytes (Graham \& Wilcox 2000), for example, is likely to enhance early post-settlement attachment and survival of these pro- 
pagules (Vadas et al. 1992), especially when the pools are uncovered by tides, and the calm water may facilitate these propagules to settle on substrates within the same pools. CCA reproduce all year round (Steneck 1986, Hall-Spencer 1994, Williams et al. 1995), and such a strategy allows rapid recruitment to occur once new substrates become available. Such rapid recruitment is important when the removal of adult biomass is greater than lateral regeneration (Kaehler \& Williams 1997). Fast re-colonization of newly released bare space from disturbance was common in all pools. In summer, the turnover rate of coralline cover on algal established plates was $\sim 3$ to $4 \mathrm{mo}$, and patterns of settlement and development were similar to those observed on new bare surfaces. Although the persistence of coralline algae relies on the grazing activities of herbivores to remove epiphytes, their ability to survive and rapidly recover from both abiotic (i.e. heat stress) and biotic (i.e. grazing pressure) disturbance allows them to be successful colonists and to dominate low-shore rock pools. This frequent disturbance and re-colonization results in the typical mosaic of patches of thin, newly settled CCA in between the developed, thicker CCA seen in low-shore rock pools in Hong Kong.

Acknowledgements. The authors thank their colleagues in the Rocky Shore Ecology group (Department of Ecology \& Biodiversity, The University of Hong Kong) for their help in the field; Prof. B. Darvell (The University of Hong Kong) for providing us with dental wax; Dr. L. Benedetti-Cecchi for his useful comments on statistical analyses; and the referees whose comments helped improve the clarity of the manuscript. This research was conducted in partial fulfillment of a PhD degree by T.-C. Wai, who was supported by a postgraduate studentship at The University of Hong Kong. Permission to work at the Cape d'Aguilar Marine Reserve was granted by the Agriculture, Fisheries and Conservation Department, Hong Kong Government, HKSAR, China.

\section{LITERATURE CITED}

Adey WH, Vassar JM (1975) Colonization, succession and growth rates of tropical crustose coralline algae (Rhodophyta, Cryptonemiales). Phycologia 14:55-69

Airoldi L (2000) Responses of algae with different life histories to temporal and spatial variability of disturbance in subtidal reefs. Mar Ecol Prog Ser 195:81-92

Airoldi L, Virgilio M (1998) Responses of turf-forming algae to spatial variations in the deposition of sediments. Mar Ecol Prog Ser 165:271-282

Andrew NL, Viejo RM (1998) Ecological limits to invasion of Sargassum muticum in northern Spain. Aquat Bot 60:251263

Ayling AM (1981) The role of disturbance in temperate subtidal encrusting communities. Ecology 62:830-847

Benedetti-Cecchi L (2000) Predicting direct and indirect interactions during succession in a mid-littoral rocky shore assemblage. Ecol Monogr 70:45-72

Benedetti-Cecchi L, Cinelli F (1994) Recovery of patches in an assemblage of geniculate coralline algae: variability at different successional stages. Mar Ecol Prog Ser 110:9-18

Bulleri F, Bertocci I, Micheli F (2002) Interplay of encrusting coralline algae and sea urchins in maintaining alternative habitats. Mar Ecol Prog Ser 243:101-109

Chapman MG, Underwood AJ (1998) Inconsistency and variation in the development of rocky intertidal algal assemblages. J Exp Mar Biol Ecol 224:265-289

Coleman MA (2003) Effects of ephemeral algae on coralline recruits in intertidal and subtidal habitats. J Exp Mar Biol Ecol 282:67-84

Connell JH, Slatyer RO (1977) Mechanisms of succession in natural communities and their role in community stability and organization. Am Nat 111:1119-1144

Connell SD (2003) The monopolization of understorey habitat by subtidal encrusting coralline algae: a test of the combined effects of canopy-mediated light and sedimentation. Mar Biol 142:1065-1071

Dethier MN (1984) Disturbance and recovery in intertidal pools: maintenance of mosaic patterns. Ecol Monogr 54:99-118

Dethier MN, Steneck R (2001) Growth and persistence of diverse intertidal algal crusts: survival of the slow in a fastpaced world. Mar Ecol Prog Ser 223:89-100

Fabricius K, De'ath G (2001) Environmental factors associated with the spatial distribution of crustose coralline algae on the Great Barrier Reef. Coral Reefs 19:303-309

Farrell TM (1989) Succession in a rocky intertidal community: the importance of disturbance size, and position within a disturbed patch. J Exp Mar Biol Ecol 128:57-73

Figueiredo MAdeO, Norton TA, Kain JM (1997) Settlement and survival of epiphytes on two intertidal crustose coralline algae. J Exp Mar Biol Ecol 213:247-260

Graham LE, Wilcox LW (2000) Algae. Prentice-Hall, Englewood Cliffs, NJ

Hall-Spencer JM (1994) Biological studies on nongeniculate Corallinaceae. PhD thesis, University of London

Hawkins SJ, Hartnoll RG (1983) Grazing of intertidal algae by marine invertebrates. Oceanogr Mar Biol Annu Rev 21: 195-282

Hawkins SJ, Hartnoll RG, Kain JM, Norton TA (1992) Plant-animal interactions on hard substrata in the north-east Atlantic. In: John DM, Hawkins SJ, Price JH (eds) Plant-animal interactions in the marine benthos, Systematics Association Spec Vol 46. Clarendon Press, Oxford, p 1-32

Hodgkiss IJ (1984) Seasonal patterns of intertidal algal distribution in Hong Kong. Asian Mar Biol 1:49-57

Johansen HW (1981) Coralline algae. A first synthesis. CRC Press, Boca Raton

Kaehler S, Froneman PW (1999) Temporal variability in the effects of grazing by the territorial limpet Patella longicosta on the productivity of the crustose algae Ralfsia verrucosa. S Afr J Sci 95:121-122

Kaehler S, Williams GA (1996) Distribution of algae on tropical rocky shore: spatial and temporal patterns of noncoralline encrusting algae in Hong Kong. Mar Biol 125: 177-187

Kaehler S, Williams GA (1997) Do factors influencing recruitment ultimately determine the distribution and abundance of encrusting algae on seasonal tropical shores? Mar Ecol Prog Ser 156:87-96

Kennish R, Williams GA, Lee SY (1996) Algal seasonality on an exposed rocky shore in Hong Kong and the dietary implications for the herbivorous crab Grapsus albolineatus. Mar Biol 125:55-64

Lawrence JM (1975) On the relationships between marine plants and sea urchins. Oceanogr Mar Biol Annu Rev 13: 213-286 
McClanahan TR (1997) Primary succession of coral-reef algae: differing patterns on fished versus unfished reefs. J Exp Mar Biol Ecol 218:77-102

Moore HB (1972) Aspects of stress in the tropical marine environment. Adv Mar Biol 10:217-269

Morritt D, Williams GA (2000) Osmoregulation in the highshore crab Grapsus albolineatus from Cape d'Aguilar, Hong Kong. In: Morton B (ed) Proceedings of the 3rd international marine biological workshop. The marine flora and fauna of Hong Kong and southern China. Hong Kong University Press, p 277-286

Morton B, Harper E (1995) An introduction to the Cape d'Aguilar marine reserve, Hong Kong. Hong Kong University Press

Paine RT (1984) Ecological determinism in the competition for space. Ecology 65:1339-1384

Paine RT, Levin SA (1981) Intertidal landscape: disturbance and the dynamics. Ecol Monogr 51:145-198

Pickett STA, White PS (1985) The ecology of natural disturbance and patch dynamics. Academic Press, New York

Smith JE, Smith CM, Hunter CL (2001) An experimental analysis of the effects of herbivory and nutrient enrichment on benthic community dynamics on a Hawaiian reef. Coral Reefs 19:332-342

Sousa WP (1984) Intertidal mosaics: patch size, propagule availability, and spatially variable patterns of succession. Ecology 65:1918-1935

Sousa WP (1985) Disturbance and patch dynamics on rocky intertidal shores. In: Pickett STA, White PS (eds) The ecology of natural disturbance and patch dynamics. Academic Press, Orlando, p 101-124

Spencer T (1992) Bioerosion and biogeomorphology. In: John DM, Hawkins SJ, Price JH (eds) Plant-animal interactions in the marine benthos, Systematics Association Spec Vol 46. Clarendon Press, Oxford, p 493-509

Steneck RS (1986) The ecology of coralline crusts: convergent

Editorial responsibility: Otto Kinne (Editor-in-Chief), Oldendorf/Luhe, Germany patterns and adaptive strategies. Annu Rev Ecol Syst 17: 273-303

Steneck RS, Watling L (1982) Feeding capabilities and limitation of herbivorous molluscs: a functional group approach. Mar Biol 68:299-319

Steneck RS, Hacker SD, Dethier MN (1991) Mechanisms of competitive dominance between crustose coralline algae: an herbivore-mediated competitive reversal. Ecology 72 : 938-950

Underwood AJ (1997) Experiments in ecology. Cambridge University Press

Underwood AJ, Jernakoff P (1984) The effects of tidal height, wave-exposure, seasonality and rock-pools on grazing and the distribution of intertidal macroalgae in New South Wales. J Exp Mar Biol Ecol 75:71-96

Vadas RL, Johnson S, Norton TA (1992) Recruitment and mortality of early post-settlement stages of benthic algae. Br Phycol J 27:331-351

Wai T-C (2004) Herbivore-induced effects and persistence of non-geniculate coralline algae in low-shore rock pools. $\mathrm{PhD}$ thesis, The University of Hong Kong

Wai T-C, Williams GA (2005) The relative importance of herbivore-induced effects on productivity of crustose coralline algae: sea urchin grazing and nitrogen excretion. J Exp Mar Biol Ecol 324:141-156

Wai T-C, Williams GA (2006) Monitoring spatio-temporal variations in molluscan grazing pressure in seasonal, tropical, low-shore rock pools. Mar Biol 149:1139-1147

Williams GA (1993) Seasonal variation in algal species richness and abundance in the presence of molluscan herbivores on a tropical rocky shore. J Exp Mar Biol Ecol 167: 261-275

Williams GA, Hall-Spencer J, Hau CH (1995) The influence of urchin grazing on encrusting coralline algae in tropical rock pools. In: Lindstrom SC, Chapman DJ (eds) Proceedings of the 15th international seaweed symposium. Valdivia, Abstracts p 109

Submitted: September 23, 2004; Accepted: March 29, 2006 Proofs received from author(s): October 11, 2006 